\title{
The influence of an audit and Regional financial ability to score regional government performance
}

\author{
Rika Henda Safitri ${ }^{1}$, Burhanuddin ${ }^{2}$, Asfeni Nurullah ${ }^{3}$ \\ \{rikahenda@unsri.ac.id ${ }^{1}$ \} \\ Sriwijaya University, Palembang, Indonesia
}

\begin{abstract}
This study aims to analyze the effect of audit opinion and the ability of regional finances on local government performance scores. The variable used to measure regional financial capacity in this study is to use regional financial dependency ratios and regional financial independence ratios with secondary data derived from the Inspection Results Summary of the BPK, APBD realization data and local government performance score data. The population used in this study is the government regional cities and regencies in South Sumatra Province with the sample used are local governments that have complete data and meet the sample criteria. The research population was 18 local governments, using secondary data for 2 years, namely 2015 and 2016. The analysis technique used was descriptive analysis and multiple regression analysis using testing tools in the form of SPSS software version 24 . The results showed that audit opinion and regional financial capacity South Sumatra, which is calculated by the proxy of dependency ratios as well as regional financial capacity which is calculated by proxy of the ratio of independence together, has a significant influence on the performance scores of the regional governments in the South Sumatra region. While partially the audit opinion and financial capability of the South Sumatra region calculated by the proxy of the independence ratio had a significant positive effect on the performance score of the South Sumatra Regional Government. And the financial capability of the South Sumatra region calculated by the dependency ratio does not significantly influence the performance score of the South Sumatra Regional Government.
\end{abstract}

Keywords: Performance Score, Audit Opinion and Regional Financial Capability.

\section{INTRODUCTION}

Local governments are given the responsibility to regulate and manage their own regions according to the principle of autonomy and assistance tasks with the principle of broadest autonomy (Undang-Undang Nomor 23 Tahun 2014). Along with the responsibilities given to the regional government, the regional government also has the obligation to report financial management responsibilities to the central government and the community through the House of Representatives in the form of Regional Government Financial Reports (Peraturan Pemerintah Nomor 8 Tahun 2006). With the Local Government Financial Report (LKPD), users of financial statements can make comparisons between financial performance and budget, assess operational results and the level of compliance with laws and regulations related to regional finance and evaluate the performance of local governments (Peraturan Pemerintah Nomor 71 Tahun 2010). In addition to LKPD, local governments must also prepare a Regional Government Implementation Report (LPPD) as a means of accountability and transparency in the performance of local governments. Inside the LPPD contains information that includes the 
administration of regional government related to decentralization matters, assistance tasks and general government tasks.

After the existence of LKPD and LPPD as a form of accountability for the implementation of local governments whose quality has been guaranteed by BPK-RI through BPK-RI audit opinions, the central government can evaluate the implementation of local governments (Peraturan Pemerintah Nomor 6 Tahun 2008). The information contained in the LPPD, is used as the central government as the main source of information for evaluating the performance of local governments in the form of Performance Evaluation of Local Government Administration (Peraturan Menteri Dalam Negeri Nomor 73 Tahun 2009). Performance Evaluation of Local Government Administration (EKPPD) is an evaluation of regional government performance in the form of a national score using Key Performance Indicators (IKK). From the results of the EKPPD process, the central government can determine the performance ratings of regional government administration nationally, sorted by performance scores, obtained by each local government, and published through a Minister of Domestic Affairs Decree on the Performance and Performance Status of Regional Government Administration.

From the audit opinion data obtained by the regional government in South Sumatra province in 2015 to 2016, the audit opinion has increased significantly. This increase is in line with the increase in the positive results of local government performance scores obtained in the period 2015 to 2016. This supports a statement stating that audit opinion influences local government performance scores, according to research (Saktiawati, 2014) the results of which state that BPK's audit opinion has a positive effect on the performance of local government operations. Based on the data above and the results of previous studies, researchers are interested in re-analyzing the influence of this opinion variable on the local government performance score.

Regional financial capability is the ability of regional governments to manage regional finances to finance their own household affairs. In this study regional financial capacity is measured by using two formulas, namely the ratio of regional financial dependency and the regional independence ratio. The ratio of regional financial dependency is calculated by comparing the amount of transfer revenue received by regional revenue with total regional revenue. The higher this ratio, the greater the level of dependence of regional governments on the central and provincial governments. The ratio of regional independence is calculated by comparing the amount of revenue received from the region with the amount of transfer revenue from the central and provincial governments and regional loans. The higher the ratio number, this ratio shows the higher the local government independence of the region (Nurhayati, 2015).

Based on the report (Realisasi APBD Tahun 2015) and (Realisasi APBD Tahun 2016) obtained from the Ministry of Finance DJPK, the ratio of regional financial dependence for local governments in South Sumatra Province has increased the ratio, where the ratio in 2015 was on average smaller than in 2016. This means that in 2016 local governments increasingly dependent on funds transfers from the central and provincial to finance the activities of his government. The increase in regional financial dependency ratios is in line with the increase in positive results from the performance score of the regional government. Ditas data can support research results from (Renas, 2014) which shows that the lower the balance fund at the regional government, the lower the performance of the regional government.

In contrast to the ratio of regional financial dependency, the ratio of regional financial independence shows a negative result where the ratio in 2015 was slightly better than in 2016 . On average the local government experienced a decline in the value of 0.1 . Decrease in the ratio of regional financial independence is not in accordance with an increase in the results of the 
performance score of the regional government. But in research (Mustikarini \& Fitriasari, 2012) states that the level of regional wealth or regional financial capacity as measured through the ratio of independence has a significant positive effect on the performance score of district / city governments. From the data on regional financial capability, both the level of dependency ratio and the independence ratio above and the results of previous studies related to this variable, researchers are interested in using the variables of regional financial dependency ratios and regional financial independence ratio variables in this study to see how much the role of these variables affect local government performance.

One of the strong reasons researchers are interested in conducting research on the performance of local government is because of the research (Saktiawati, 2014) regarding the performance of local governments, by using the variables of the results of regional financial audits by the BPK which consist of weaknesses in the internal control system, non-compliance with statutory provisions and audit opinions still cannot describe the performance of the government as a whole. The study only resulted in an adjusted R2 value of 0.180 , which means that only $18 \%$ of the variation in the performance of local government operations could be explained by the SPI's weaknesses, disobedience to the law, and BPK's audit opinion. Meanwhile, $82 \%$ is explained by variables outside the independent variables used in the study. In this study the authors used the opinion variable and added the regional financial capability variable as measured by the ratio of the level of dependency and the ratio of regional financial independence using the budget data of the regional government of South Sumatra Province for 2 years, the hope is that research on the performance of local government can produce research results that are more significant. So that it can provide tangible benefits for all groups, especially local governments in the South Sumatra Province to improve performance in their government.

\section{LITERATURE REVIEW}

\subsection{Agency Theory (Theory agency) and Audit Opinion}

Based on agency theory (theory agency) (Jensen \& Meckling, 1976) which states that the agency relationship as a contract that arises when one or more people as the owner (principal) to employ another person (agent) in order to provide a service to the principal and then delegate decision making authority to the agent.

\section{Figure 1}

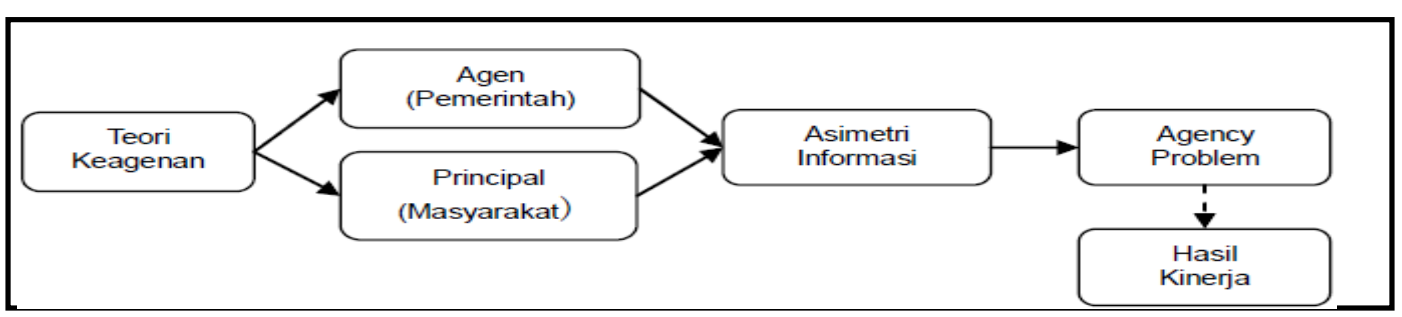

Sourches:(Nurdin, 2016)

Within the scope of local government administration in Indonesia, agency relations are applied between the people and the regional government. The relationship is like the relationship between the principal and the agent, where the people act as the principal because the people who set the contract against the local government as the agent in charge of providing services that are in the people's interest. A democratic country has an agency relationship 
between the community and the government or a relationship between the regional government and the central government (Zelmiyanti, 2016).

On the other hand the existence of BPK-RI has the duty to mediate between the interests of the people and regional government, as a giver of confidence in the administration of regional government by issuing the results of audits to the people in the form of BPK-RI Opinion on LKPD. The opinion issued by BPK-RI is the result from the examination of the Regional Government Financial Report and the Report on the Implementation of the Regional Government that has been made, in accordance with what has been done during the administration of the regional government. In other words, the opinion issued by BPK-RI is to assess and find out whether the performance of the regional government has been carried out and reported properly or improperly. This oppini can increase or decrease the level of stakeholder confidence in reporting presented by the party being audited, in terms of this is a local government entity. In research (Saktiawati, 2014) states that the more reasonable the BPK audit opinion should show the higher performance of a local government.

\subsection{Regional Financial Capability}

Local governments that have been mandated by the central government to be able to regulate and manage their own affairs must have the financial capacity to organize regional governments. Independent regions are characterized by a reduction in regional financial dependence on the center. Increasing Local Revenue (PAD) is one way to improve regional financial capacity and reduce dependence on transfer funds from both the central and direct central government. Regional financial capability is the ability of regional governments to manage regional finances to finance their own household matters, especially those originating from PAD. Regional Income in accordance with Law Number 32 Year 2004 Article 1 is the right of regional government which is recognized as an addition to the net worth in the period of the year (Undang-Undang Nomor 32 Tahun 2004). Analysis of financial performance is measured through the calculation of financial ratios which are a measure of regional financial capacity (Wahab, Rofingatun, \& Kreuta, 2016). In this study regional financial capacity is measured using two formulas, namely the ratio of the level of regional financial dependency and the ratio of regional financial independence.

\subsubsection{Regional Financial Dependency Ratio}

Dependency is a condition where an organization depends on other organizations. In the case of government organizations, local governments depend on funds provided by the central and / or provincial governments. Regional financial dependency ratio is a ratio calculated by comparing the amount of transfer revenue received with total regional income. The higher the ratio of the level of regional financial dependency, the greater the level of dependence of regional governments on central and / or provincial government revenues.

In research (Mustikarini \& Fitriasari, 2012) states that the level of regional dependence on the central government has a significant positive effect on the performance scores of district / city governments. That is, the higher the level of regional dependence on the central government, the higher the performance score of local governments. The study also stated that regional governments with a high degree of dependence on the central government made regional governments more careful in carrying out their service duties to the community because they felt they were supervised by the central government. However, this should not make local governments with low dependency levels to provide services that are not optimal to the community because local governments with low dependency levels usually have large regional original wealth (PAD).

\subsubsection{Regional Financial Independence Ratio}


The ratio of independence shows the ability of local governments to self-finance government activities, development and services to the community. The ratio of independence is calculated by the formula of Local Own Revenue (PAD) divided by transfer funds from the central and provincial governments. The higher the Regional Own Revenue owned by a region, the greater the ability of regional governments to manage finances. How big is the ability of local governments in managing finances, can be one factor to see and measure the performance of local government operations. In other words, the ability of regional finances has a role in determining the performance scores of regional government operations.

In research (Mustikarini \& Fitriasari, 2012) states the results of the level of regional wealth as measured through the value of PAD to total regional government revenue have a significant positive effect on the score of local government performance. These results are in line with research (Sudarsana \& Rahardjo, 2013) variable local wealth level with PAD proxy compared to total income significantly influences the performance score of regency / city government in Indonesia. Similar to the above research, research (Rustiyaningsih \& Immanuela, 2014) states partially PAD results and population have a significant effect on the performance of local government.

\subsection{Government Implementation Performance}

Regional heads have the obligation to compile and prepare Regional Government Financial Reports (LKPD) as a form of accountability for the performance of regional government operations. Performance is the result / output of the activity or program that is to be or has been achieved in relation to the use of the budget with measurable quantity and quality (Peraturan Pemerintah Nomor 8 Tahun 2006). The Performance of Local Government Administration (EKPPD) is the achievement of the implementation of regional government affairs as measured by inputs, processes, outputs, results, benefits, and / or impacts (Peraturan Menteri Dalam Negeri Nomor 73 Tahun 2009). The central government is obliged to conduct an evaluation of the performance of regional government administration or commonly referred to as the evaluation of regional government administration (EPPD) to find out the success of regional government implementation in utilizing the rights obtained by the region with the planned outputs and outcomes. The main purpose of the evaluation is to assess the performance of regional government in an effort to improve performance to support the achievement of the objectives of regional autonomy based on the principles of good governance.

The ranking of the performance of government administration is determined through the calculation of performance scores obtained from the results of the Regional Government Implementation Performance Evaluation (EKPPD). EKPPD is a process of collecting and analyzing data systematically on the performance of local government operations using a performance measurement system (Harumiati \& Payamta, 2014). In carrying out the EKPPD process the main source of information used is derived from the Local Government Implementation Report (LPPD) (Peraturan Menteri Dalam Negeri Nomor 73 Tahun 2009). The EKPPD is carried out by assessing the total composite index of the performance of local government administration. The total composite index of the performance of local government administration is the sum of the results of the assessment which includes the performance achievement index and material suitability index. Performance index is measured by assessing the IKK at the level of policy making and policy implementation. The report on the results of the Evaluation on the Performance Rating of Regional Government Administration was issued by the Ministry of Home Affairs in 2009 for the LPPD of the 2007 fiscal year (Mustikarini \& Fitriasari, 2012). The ranking of the performance of government administration is carried out annually and is determined and published in a Decree of the Minister of Home Affairs. The main objective of the evaluation is to assess the performance of the administration of regional 
government in an effort to improve performance to support the achievement of the objectives of regional autonomy based on the principles of good governance (Arifianti, Payamta, \& Sutaryo, 2013). Each local government certainly wants a good ranking and performance status in order to maintain the existence of the government and for the growth of the organization of the government so that it will be better in the future and be able to maintain good relations with stakeholders such as the community, the House of Representatives and the central government.

\subsection{Prior Research}

Research (Saktiawati, 2014) examine the effect of internal control system findings, local government compliance with statutory regulations and audit opinions on local government financial performance. The population in this study is the district / city level local government in Indonesia and the sampling technique uses purposive sampling technique. The data used in this study are secondary data sourced from Minister of Home Affairs Decree number 120-2818 in 2013, IHPS I and II in 2011 and Examination Results Report on Regional Government Financial Statements for fiscal year 2011. In this study the results state that: (1) Weaknesses of regional government SPI negatively affect the performance of local government administration, where an effective SPI can produce higher performance. (2) Non-compliance with the law has a significant negative effect on the performance of local government administration, where the higher the number of audit findings related to non-compliance will indicate the lower performance of a local government. (3) BPK's audit opinion has a positive effect on the performance of regional government administration.

Research (Rustiyaningsih \& Immanuela, 2014) entitled Factors Affecting Local Government Performance. This study uses a purposive sampling technique with the criteria of district / city local governments that have complete data. The data are in the form of Budget Realization Report (LRA), regional balance sheet, BPK audit report, evaluation results of government administration performance, and population. The results of this study are: (1) Together with the regional size, PAD, regional expenditure, balance funds, population, and BPK audit results have a significant effect on the performance of local governments because the significance value is below 0.05. (2) Partially PAD and population have a significant effect on the performance of regional government. (3) Size, regional expenditure, balance fund, and BPK audit results do not significantly influence the performance of regional governments.

Research (Harumiati \& Payamta, 2014) entitled the influence of local government characteristics and BPK audit findings on the performance of district / city local governments in Indonesia for the 2011 fiscal year. The sampling technique was purposive sampling by selecting district / city governments that met the criteria set by the authors. The sample in this study were 243 district / city local governments in Indonesia. This study shows the results that the level of regional wealth (PAD), capital expenditure (BM), and audit findings (FINDINGS) have a significant effect on the performance of local government administrators, but for the variable capital expenditure (BM) it does not. Meanwhile, the regional size variable (ASET) does not affect the performance of local government administrators. The variable level of dependency on the central government (DAU) and regional status (STATUS) does not affect the performance of local government administrators.

Research (Sudarsana \& Rahardjo, 2013) entitled The Effect of Local Government Characteristics and BPK Audit Findings on Local Government Performance (Study of Regency / City Governments in Indonesia). The data used in this study are the balance sheet to get total assets, Budget Realization Report (LRA) to get PAD, DAU, and total revenue realization budget, and require a BPK audit report in 2010 to get the number of audit findings. The results of this study stated that the variable size of local government with total assets proxy, the variable level of regional dependence on the central government with DAU proxy compared to total 
income and capital expenditure variable with capital expenditure proxy compared to total expenditure realization proved to have no significant effect on the score of district government performance /city. Meanwhile, the BPK audit findings variable with the audit findings proxy compared to the total budget, the regional wealth level variable with the PAD proxy compared to the total revenue significantly influences the performance score of regency / city local governments in Indonesia.

Research (Mustikarini \& Fitriasari, 2012) which examines the influence of local government characteristics and BPK audit findings on local government performance. The population in this study is the district / city government in Indonesia. This study uses cross section data by taking LKPD and LPPD data for fiscal year 2007. Data for the BPK audit findings variable was obtained from the Audit Inspection Overview for semester I and II of 2008. The audit findings used in this study were the findings of an audit of LG non-compliance with laws and regulations. invitation for fiscal year 2007. The results of this study show that regional size, regional wealth and the level of regional dependence on the central government have a positive effect on local government performance scores, while regional expenditure variables and BPK audit findings negatively affect local government performance scores.

\subsection{Framework} follows:

The conceptual framework used in the research of the authors draws in Figure 3.2 as

Figure 2 Hypothesis Thinking Framework

\begin{tabular}{||l|l|l|}
\hline OpiniAudit $\left(X_{1}\right)$ & Skor \\
\hline \hline Ketergantungan Keuangan Daerah $\left(X_{2}\right)$ & & KinerjaPemerint \\
ah Daerah $(\mathrm{Y})$
\end{tabular}

Sumber : Diolah penulis (2019)

\subsection{Hypothesis Development}

2.6.1. The Hypothesis of Relationship between Audit Opinion and Local Government Performance Scores

Judging from the audit opinion data obtained by the regional government in South Sumatra province in 2015 to 2016, the audit opinion has increased significantly. In 2015 there were 13 local governments that received WTP opinions, while in 2016 as many as 17 local governments received WTP opinions (Ikhtisar Hasil Pemeriksaan Semester II Tahun 2017). The increase in opinion achievement is in line with the increase in positive results from the local government performance scores obtained in the period 2014 to 2016. This is consistent with the results of the study (Saktiawati, 2014) which states that BPK's audit opinion has a positive effect on the performance of local government administration.

Based on these reviews, the hypotheses that can be developed in this study are: $\mathrm{H}_{1}=$ Audit opinion has a positive effect on local government performance scores. 
2.6.2. The Hypothesis of the Relationship Ratio of Regional Financial Dependence Levels to Local Government Performance Scores

Based on the report (Realisasi APBD Tahun 2015) and (Realisasi APBD Tahun 2016) obtained from the Ministry of Finance DJPK, the financial capacity of the regions in South Sumatra Province as measured by the ratio of the level of dependency from 2015 to 2016 on average experienced an increase in the ratio. This means that in 2016 the regional governments in the South Sumatra Province are increasingly dependent on transfer funds from the central government and / or provincial governments to manage and finance their government affairs. This increase in ratio is in line with the increase in the performance score of the regional government in the South Sumatra Province. This is consistent with the results of the study (Mustikarini \& Fitriasari, 2012) which states that the level of regional dependence on the central government has a significant positive effect on the performance score of district / city local governments. That is, the higher the level of regional dependence on the central government, the higher the performance score of local governments. The study also stated that regional governments with a high degree of dependence on the central government made regional governments more careful in carrying out their service duties to the community because they felt they were supervised by the central government.

Based on these reviews, the hypotheses that can be developed in this study are:

$\mathrm{H}_{2}=$ The ratio of the level of regional financial dependence has a positive effect on local government performance scores.

\subsubsection{Hypothesis of the Relationship Ratio of Regional Financial Independence to Local Government Performance Scores}

Based on the report (Realisasi APBD Tahun 2015) and (Realisasi APBD Tahun 2016) obtained from the Ministry of Finance DJPK, the financial capacity of the region in the South Sumatra Province as measured by the ratio of independence from 2015 to 2016 on average experienced a decline in the value of the ratio of 0.01 to 0.1 . The decrease in the value of the independence ratio is inversely proportional to the increase in the results of the local government performance score in the province of South Sumatra. In research (Mustikarini \& Fitriasari, 2012) states that the level of regional wealth or regional financial capacity as measured through the ratio of independence has a significant positive effect on the performance score of district / city governments.

Based on these reviews, the hypotheses that can be developed in this study are:

$\mathrm{H}_{3}=$ Regional financial independence ratio has a positive effect on the performance score of local governments.

\section{RESEARCH METHOD}

\subsection{Types of research}

Based on the formulation of the problem, this type of research can be classified as quantitative research. Quantitative research is a process of finding knowledge that uses data in the form of numbers as a means of analyzing information about what you want to know (Radjab 
\& Jam'an, 2017). This research uses secondary data. Theory or hypothesis testing is done by measuring the research variables with numbers and conducting data analysis with statistical procedures.

\subsection{Population, Samples and Sampling Sampling Techniques}

The population in this study is the district / city and provincial governments in the South Sumatra Province. With the sample, that is, the local government has all the complete data including: Realization of Regional Revenue and Expenditure Budget (APBD) obtained through the website of the Directorate General of Fiscal Balance Ministry of Finance to obtain data on Regional Original Revenue (PAD), transfer funds and total revenue used to measure the ratio of the level of dependency and the ratio of regional financial independence. Summary of Semester I and II Audit Results which are accessed through the website of the Supreme Audit Board (BPK) to obtain audit opinion data. As well as data on local government performance scores obtained through the Minister of Home Affairs' decisions regarding the ranking and status of local government performance for 2015 and 2016.

The sampling technique used in conducting this research is the purposive sampling technique. The purposive sampling is a sampling method based on certain criteria (Radjab \& Jam'an, 2017). Researchers used this sampling technique due to data limitations and easy access to data that can be used in this study. The criteria and results of the sampling of this study include:

1. Regional government in the area of South Sumatra Province.

2. The regional government in the South Sumatra Province does not have complete data.

\subsection{Data Types and Sources}

The data used in this study is panel data (Pooled data). Panel data is a combination of time series data and cross section. Data sources consist of:

1. Determination of the Ranking and Status of Performance of National Local Government Implementation in 2015 published in the Decree of the Minister of Home Affairs Number 120-10421 of 2016.

2. Determination of Ranking and Status of Performance of National Local Government Implementation in 2016 published in Decree of the Minister of Home Affairs Number $100-53$ of 2018

3. Summary of Examination Results for Semester I and II of 2017 published through the website of the Supreme Audit Board which is used to obtain audit opinion data.

\subsection{Data collection technique}

The data collection technique used in this study is to use the document study method. Document review is a means of researchers in gathering data or information by reading letters, announcements, summaries of meetings of certain policy written statements and other written materials (Nilamsari, 2014). This data search method is very useful because it can be done without disturbing the object or the atmosphere of the study. Researchers by studying these documents can recognize the culture and values adopted by the object under study.

\subsection{Operational Definition and Variable Measurement}

The definitions of each variable in this study will be presented in Table 3.1 as follows: Table 3.1 Definition of Operational Variables

\begin{tabular}{|l|l|l|}
\hline Variabel & Operational definition & Size Scale \\
\hline Performance Score (Y) & Scores are the performance of the & Nominal \\
\hline
\end{tabular}




\begin{tabular}{|l|l|l|}
\hline & $\begin{array}{l}\text { implementation of the Regional Government } \\
\text { issued by the Minister of the Interior in 2015 } \\
\text { and 2016 }\end{array}$ & $\begin{array}{l}\text { BPK's audit opinion is taken from IHPS II data } \\
\text { for 2017 published by BPK. Under the } \\
\text { condition :WTP=5, WTP DPP =4, WDP = , } \\
\text { TW }=2, \text { TMP }=1 .\end{array}$ \\
\hline $\begin{array}{l}\text { Rudit Opinion (X1) Nominal } \\
\text { Dependence (X2) }\end{array}$ & $\begin{array}{l}\text { Regional financial capability is measured by } \\
\text { the ratio of the level of dependency in the } \\
\text { formula: } \\
\text { Dependency Ratio = Transfer Funds / (Total } \\
\text { Revenue) }\end{array}$ & Rasio \\
\hline $\begin{array}{l}\text { Regional Financial } \\
\text { Independence (X3) }\end{array}$ & $\begin{array}{l}\text { Regional financial capability is measured by } \\
\text { the ratio of independence in the formula: } \\
\text { Independence Ratio = PAD / Transfer Fund }\end{array}$ & Rasio \\
\hline
\end{tabular}

Source: Author processed (2019)

\subsection{Analysis Techniques}

In this quantitative study the testing method used to test the hypotheses that have been made is by using multiple linear regression test, using a testing tool that is SPSS 2.0. Multiple linear regression test is done because the number of variables used is more than one variable. The independent variables used are audit opinion, the ratio of the level of regional financial dependency and the ratio of regional financial independence that will be tested against the dependent variable, namely the performance score of the local government.

\subsubsection{Analysis Model}

The test method uses multiple regression test, with the analysis model used in this study is

With the following conditions:

$$
\mathrm{Y}=\alpha+\beta 1 \mathrm{X} 1+\beta 2 \mathrm{X} 2+\beta 3 \mathrm{X} 3+\varepsilon .
$$

$\mathrm{Y}=$ Local Government Performance Score

$\mathrm{X} 1=$ Audit Opinion

X2 = Regional Financial Dependency Ratio

X3 = Regional Financial Independence Ratio

$\alpha=$ Constant

$\beta 1, \beta 2, \beta 3=$ Regression Coefficient

$\varepsilon=$ Standard Error

\subsubsection{Classic Assumption Test Data}

The classic assumption test is done because it becomes one of the requirements for conducting multiple regression tests, in order to show a valid and unbiased relationship it is necessary to test the classic assumptions on the regression model used. The following is the classic assumption test model used:

\subsubsection{Residual Normality Test}

Residual normality test is used to test whether the data distribution follows or approaches the normal distribution, good data is data with normal distribution patterns. The test can be done using Kai Squared, Kolmogorov-Smirnov, Lilieford Test, Skewness and Kurtosis, or Jarque-Fallow Test (Radjab \& Jam'an, 2017). In this study 
normality testing was conducted by the Kolmogrovsmirnov method, by looking at the significance value at 0.05 . If the resulting significance value $\geq 0.05$ then it is normally distributed.

\subsubsection{Muliticollinearity Test}

Multicollinearity is a situation of correlation between independent variables with one another, then one of the independent variables is eliminated. If there is no correlation of the independent variables then there is no multicollinearity problem. Testing can be done by correlation / regression analysis, tolerance, and VIF (Variance Inflation Factor) (Radjab \& Jam'an, 2017). In this study multicollinearity was seen through the value of variance inlation factor $(\mathrm{VIF}) \leq 10$ and tolerance $\geq 0.10$.

\subsubsection{Heteroscedasticity Test}

Heteroscedasticity test is used to assess whether there is a variance in variance of the receipts for all observations. Testing can be done with Park Test, Glesjer Test, Bartlett Test, RhoSpearman, and Goldfield \& Quant (Radjab \& Jam'an, 2017). Testing can be done by looking at the presence or absence of certain patterns in the graph of partial regression plot (scatter plot). Data that are not heteroscedasticity are data that do not form certain patterns and the points spread above and below zero on the $\mathrm{Y}$ axis.

\subsubsection{Model Test}

\subsubsection{Hypothesis Test (t test)}

Statistical t-test (t-Test) aims to find out the significant relationship of each independent variable on the dependent variable. To see the effect of the independent variable on the dependent variable, it is tested with a significant level $\alpha=0.05$, the hypothesis conclusions presented for $\mathrm{H}_{1}, \mathrm{H}_{2}$, and $\mathrm{H}_{3}$ based on:

1. If the significant level $\leq(\alpha)=0.05$ and has a positive regression coefficient, then the null hypothesis ( $\mathrm{H} 0)$ is rejected and sufficient evidence is available to accept alternative hypotheses $\left(\mathrm{H}_{1}, \mathrm{H} 2\right.$ and $\left.\mathrm{H}_{3}\right)$ so that it can be said audit opinion, the ratio of the level Regional financial dependency and regional financial independence ratios have a positive effect on local government performance scores.

2. If a significant level $\geq(\alpha)=0.05$ and has a negative regression coefficient or if a significant level $\leq(\alpha)=0.05$ and has a negative regression coefficient, then the null hypothesis $(\mathrm{H} 0)$ is accepted and the alternative hypothesis $\left(\mathrm{H}_{1}, \mathrm{H}_{2}\right.$ and $\left.\mathrm{H}_{3}\right)$ is rejected. Thus it can be said that audit opinion, the ratio of regional financial dependency and the ratio of regional financial independence negatively affect the performance score of local governments

\subsubsection{The coefficient of determination (R-square)}

The determination test $\left(\mathrm{R}^{2}\right)$ is to measure the proportion of variation of the dependent variable explained by the independent variable or measure which states the contribution of the independent variable in explaining its effect on the dependent variable. This means that the greater the value of $\mathrm{R}^{2}$, the better the regression model with existing data, so the more appropriate this model can be used to explain the dependent variable by the dependent variable.

\section{ANALYSIS AND DISCUSSION}

Based on the results of the study, it is known that the number of observations in the study $(\mathrm{N})$ is 12 . The audit opinion has a minimum value of 1 or is categorized as a TMP opinion and a maximum value of 5 or is categorized as a WTP opinion. With a mean value of 4.1154 while the 
standard deviation of 0.778499 . This means that the mean value is greater than the standard deviation which indicates that the results are good. That is because the standard deviation is a very high reflection, so that the spread of data shows normal results and does not cause bias. We can see that the average audit opinion in the South Sumatra region is 5, which means getting a WTP audit opinion. This proves that the quality of local government financial reports in the South Sumatra region is already good, during 2015 to 2016 the development of opinion has always improved as evidenced by the increase in the acquisition of WTP opinion from as many as 13 to 17 local governments or by $30 \%$.

The ratio of regional financial dependency has a minimum value of 0.51 and a maximum value of 0.85 . With a mean value of 0.7474 while the standard deviation of 0.07746 . This means that the mean value is greater than the standard deviation which indicates that the results are good. That is because the standard deviation is a very high reflection, so that the spread of data shows normal results and does not cause bias. The average regional financial dependency ratio of regional governments in the South Sumatra region is 0.7474 , meaning that $74.74 \%$ of local government revenue comes from the central government. This shows that the dependence of the regional government in the South Sumatra region is still high on the central government. follows:

Descriptive statistical analysis for the research variables can be seen in table 4.1 as

Table 4. 1 Descriptive Statistics Test Results

\begin{tabular}{|c|c|c|c|c|c|}
\hline & $\mathbf{N}$ & Minimum & Maximum & Mean & Std.Deviation \\
\hline Opini Audit $\left(\mathrm{X}_{1}\right)$ & 12 & 3 & 5 & 4,1154 & 0,778499 \\
\hline Rasio Ketergantugan $\left(\mathrm{X}_{2}\right)$ & 12 & 0,51 & 0,8 & 0,7474 & 0,07746 \\
\hline Rasio Kemandirian $\left(\mathrm{X}_{3}\right)$ & 12 & 0,05 & 0,5 & 0,1091 & 0,120114 \\
\hline Skor Kinerja (Y) & 12 & 2,6741 & 3,1362 & 2,951832 & 0,136097 \\
\hline Valid N (listwise) & 12 & & & & \\
\hline
\end{tabular}

Source: Secondary data is processed through SPSS

Regional financial independence ratio has a minimum value of 0.05 and a maximum value of 0.5 . With a mean value of 0.1091 while the standard deviation of 0.120114 . This means that the mean value is smaller than the standard deviation which indicates that the results are not good. That is because the standard deviation is a very high reflection, so that the spread of data shows normal results and does not cause bias. The ratio of local government independence in the South Sumatra region averaged 0.1091 or $10.91 \%$. This means that financial independence sourced from Regional Original Revenue in the South Sumatra region is still very low. Overall the level of financial independence from 2015 to 2016 has decreased.

The dependent variable performance score has a minimum value of 2.6741 and a maximum value of 3.1362 . With a mean value of 2.951832 while the standard deviation of 0.136097 . This means that the mean value is greater than the standard deviation which indicates good results so that the spread of data shows normal results and does not cause bias. Local government performance scores in South Sumatra an average of 2.951832 this score included in the high performance category. This means that the performance of regional governments in the South Sumatra region on average has a fairly good performance. The lowest performance score was obtained by the City Government of Pagar Alam in 2015 with a score of 2.6741, but this result can still be categorized as high performance. The highest performance score was obtained by the Ogan Kemering Ilir district government in 2016 with a performance score of 3.1362 with 
a very high performance category. Overall, the performance of regional governments in South Sumatra has quite good performance, but when compared with the performance of regional governments in Java, the performance is still far better than the performance of regional governments in South Sumatra.

\subsection{Hypothesis Test Analysis}

\subsubsection{Analysis of Multiple Regression}

The determinants used in this research are audit opinion, regional financial dependency ratio and regional financial independence ratio. The results of multiple regression tests that indicate the direction of the change of the dependent variable to the independent variable can be seen in table 4.2 below:

Table4.2 Multiple Regression Test Results

\begin{tabular}{|l|l|r|r|}
\hline \multicolumn{2}{|l|}{ Model } & \multicolumn{2}{|c|}{$\begin{array}{c}\text { Unstandardized } \\
\text { Coefficients }\end{array}$} \\
\cline { 3 - 4 } & (Constant) & \multicolumn{1}{c|}{ B } & Std. Error \\
\hline 1 & Opini Audit (X1) & 2,040 &, 936 \\
\hline & Rasio Ketergantungan (X2) &,- 020 &, 058 \\
\hline & Rasio Kemandirian (X3) & 1,304 & 1,116 \\
& &, 708 &, 718 \\
\hline
\end{tabular}

a. Dependent Variable: Skor Kinerja (Y)

Source: Secondary data processed through SPSS

$$
\mathrm{Y}=2,040+\left(-0,020 \mathrm{X}_{1}\right)+1,304 \mathrm{X}_{2}+0,708 \mathrm{X}_{3}
$$

The research model of aggression and above is meaningful:

The coefficients of the multiple linear regression equation above can be interpreted as a regression coefficient for a constant of 2.040 indicating that if the audit opinion variable, the ratio of regional financial dependency and the ratio of regional financial independence is zero or does not go up or down or is constant (fixed) then the value the performance score is 2,040 .

1. The audit opinion variable of -0.020 shows that if the audit opinion variable increases by 1 unit it will reduce the performance score of the Regional Government by -0.020 units, with the other variables being considered constant.

2. The regional financial dependency ratio variable of 1.304 indicates that if the regional financial dependency ratio variable increases by 1 unit, it will increase the performance score of the Regional Government by 1.304 units, provided that other variables are considered constant.

3. The variable local financial independence ratio of 0.708 indicates that if the regional financial independence ratio variable increases by 1 unit, it will increase the performance score of the Regional Government by 0.708 units, provided that other variables are considered constant. 


\subsubsection{Partial Test ( $t$ test)}

The $t$ test was used to determine whether the independent variable consisting of audit opinion, the ratio of regional financial dependency and the ratio of regional financial independence partially had a significant effect on the dependent variable, namely the local government performance score. The test was carried out using a significance level of $0.05(\alpha=5 \%)$. Rejection or hypothetical acceptance is carried out with the following criteria:

a. If the significance value $>0.05$ then the hypothetical is rejected (the coefficient of regression is not significant) this means that partially the independent variable has no significant effect on the dependent variable.

b. If the significance value $<0.05$ then the hypothesis cannot be rejected (significant regression coefficient) this means that partially the independent variable has a significant effect on the dependent variable.

Partial test results ( $\mathrm{t}$ test) can be seen in table 4.3 below:

Table 4.3 Result Uji t

Coefficients ${ }^{\mathrm{a}}$

\begin{tabular}{|ll|r|r|r|r|r|}
\hline \multicolumn{1}{|l|}{ Model } & \multicolumn{2}{|c|}{ Unstandardized Coefficients } & \multicolumn{1}{c|}{$\begin{array}{c}\text { Standardized } \\
\text { Coefficients }\end{array}$} & \multicolumn{1}{c|}{ Sig. } & \\
\cline { 3 - 5 } & \multicolumn{1}{|c|}{ B } & Std. Error & \multicolumn{1}{c|}{ Beta } & & \\
\hline \multirow{4}{*}{1} & 2,040 &, 936 & & 2,178 &, 061 \\
& (Constant) &,- 020 &, 058 &,- 113 &,- 338 &, 744 \\
& Opini & 1,304 & 1,116 &, 742 & 1,168 &, 276 \\
& Rasio_Ketergantungan &, 708 &, 718 &, 625 &, 986 &, 353 \\
\hline
\end{tabular}

a. Dependent Variable: Skor_Kinerja

Source: Secondary data is processed through SPSS

From table 4.3 above it can be explained the proof of each hypothesis in this study as follows:

The audit opinion variable has a $t$ value of -0.333 with a significance level of 0.744 , which means it is less than 0.05 . This means that this research successfully demonstrated a positive and significant effect between audit opinion variables and performance score variables, which means that audit opinion has a significantly positive effect on LG performance scores.

Regional financial dependency ratio variable has a t value of 1.168 with a significance level of 0.276 which means greater than 0.05 . This means that this study failed to show a significant effect between the variables of regional financial dependency ratios and performance score ratios, which means that local financial dependency ratios did not significantly influence local government performance scores.

The regional financial independence ratio variable has a $t$ value of 0.986 with a significance level of 0.353 which means it is smaller than 0.05 . This means that this study successfully demonstrated a positive and significant effect between the regional financial independence ratio variable and the performance score variable, which means that the regional financial independence ratio had a significantly positive effect on the local government performance score. 


\subsubsection{Simultaneous Test (F Test)}

The F test is used to see the effect of the independent variables together (simultaneously) on the dependent variable as well as to see the feasibility of the research model. F test is done by looking at the significance value and the calculated $\mathrm{F}$ value. The lower the significance value indicates that the model built has a lower probability of error. This F test is carried out with the following conditions:

a. If the significance value is $>0.05$ then the hypothesis is rejected (the regression coefficient is not significant) this means that simultaneously the independent variable has no significant effect on the dependent variable.

b. If the significance value $<0.05$ then the hypothesis cannot be rejected (significant regression coefficient) this means that simultaneously the independent variable has a significant effect on the dependent variable.

c. If the significance value $<0.05$, it can be concluded that the regression model in this study is considered feasible and good to use.

The following F statistical test results in this research model:

Table 4.4 Test Results F

ANOVA ${ }^{a}$

\begin{tabular}{|rl|r|r|r|r|r|}
\hline Model & & Sum of Squares & df & Mean Square & F & Sig. \\
\hline \multirow{2}{*}{1} & Regression &, 033 & 3 &, 011 &, 523 &, $078^{\mathrm{b}}$ \\
& Residual &, 170 & 8 &, 021 & & \\
& Total &, 204 & 11 & & & \\
\hline
\end{tabular}

a. Dependent Variable: Skor_Kinerja

b. Predictors: (Constant), Rasio_Kemandirian, Opini, Rasio_Ketergantungan

Source: Secondary data is processed through SPSS

From table 4.4 of the Anova test results above, it is known that the calculated F value is 0.523 and the significance value is 0.078 . This leads to the conclusion that when the significant value is below 0.05 then the hypothesis cannot be rejected or the regression coefficient is significant, this means that together the three independent variables have a significant effect on the dependent variable. In conclusion, the audit opinion, the ratio of regional financial dependency and the ratio of regional financial independence together affect the local government performance score. And these results prove that the research model is feasible and good to use.

\subsubsection{Determination Coefficient Test $\left(\mathbf{R}^{2}\right)$}

The following are the results of the determination test presented in table 4.5:

Table 4.5 Determination Coefficient Test Results 
Model Summary ${ }^{\mathrm{b}}$

\begin{tabular}{|l|r|r|r|r|}
\hline Model & \multicolumn{1}{|c|}{ R } & R Square & Adjusted R Square & Std. Error of the Estimate \\
\hline 1 &, $405^{\mathrm{a}}$ &, 164 & .149 &, 1459133 \\
\hline
\end{tabular}

a. Predictors: (Constant), Rasio_Kemandirian, Opini, Rasio_Ketergantungan

\section{b. Dependent Variable: Skor_Kinerja}

Source: Secondary data is processed through SPSS

From the coefficient of determination (Adjusted $\mathrm{R}^{2}$ ) it can be seen the degree of accuracy of the multiple linear regression analysis shows the magnitude of the variation of the contribution of three independent variables to the dependent variable. The results of the output display in the model summary table show that the adjusted $\mathrm{R}$ square value is 0.149 or $14.9 \%$. Then the magnitude of the influence of the independent variable on the dependent variable is $14.9 \%$, while the remaining $85.1 \%$ is explained by other independent variables outside this study.

\subsection{Discussion}

\section{The Effect of Audit Opinions on Local Government Performance Scores}

The results of the multiple linear coefficient test showed that the significance level of audit opinion was $-0.020<0.05$. This shows that audit opinion has a significant positive effect on LG performance scores. From these results it can be concluded that the first hypothesis stating that audit opinion has a positive effect on LG performance scores is acceptable (H1 accepted). This reflects that the audit opinion obtained by the Regional Government positively and significantly affects the performance achievement of the regional government.

The results of this study support the research Saktiawati (2014) which states that BPK's audit opinion has a positive effect on the performance of regional government administration, which means that the higher the achievement of opinion obtained by a local government, the higher the performance score of that regional government. But the results of this study have different results with the results of the study Rustiyaningsih dan Immanuela (2014) which states that the BPK audit results have no significant effect on local government performance.

Research in this variable has a significant positive effect because it can be concluded that the Regional Government with a good audit opinion means having a good report quality, so that the financial performance in the government has been directed and effective and will have an impact on improvements in the performance of government administration. To get a very high performance score means the Regional Government must first fix the financial statements and financial performance in the local Government in order to get a WTP audit opinion so that the achievement of the performance score will also be even higher. This result also proves that the better the audit opinion obtained by the regional government, the better the performance of the regional government will be.

\section{Effect of Dependency Ratio on Local Government Performance Scores}

The results of the multiple linear coefficient test indicate that the level of significance of regional financial dependency ratios is $1.304>0.05$. This shows that the ratio of regional 
financial dependency does not significantly influence the performance score of local governments. From these results it can be concluded that the second hypothesis stating that the ratio of regional financial dependence has a positive effect on the performance score of local governments is unacceptable (H2 rejected). An increase or decrease in the value of regional financial dependency ratios does not affect the probability of an increase in local government performance scores. This indicates that the role of transfer funds from the central government for the regions in improving the performance score of the local government has not been able to function properly if seen partially.

The results of this study support the research Sudarsana dan Rahardjo (2013) which states that the level of regional financial dependence on the central government does not significantly influence the performance score of district / city governments. Similar to the results of the research above, research Harumiati dan Payamta (2014) also mentioned that the variable level of dependency on the central government does not affect the performance of local government administration. But the results of this study are different from the results of the study Mustikarini dan Fitriasari (2012) which states there is a positive influence between the variable level of dependence on local government performance scores.

Research in this variable has no effect because it can be concluded that the higher the level of regional financial dependence on the central government, it will not affect the performance score of local governments. This happens because the higher the level of dependence of local governments on the central government, the regional governments will be limited in implementing their government because the income they have is largely dependent on gifts from the central government. The level of dependence of the central government on the performance score of regional administrators is not likely due to the use of transfer funds from the central government to the regions that is still ineffective and inefficient, in accordance with key performance indicators (IKK) in measuring the performance of local government operations. In addition, the regional government also cannot control the governance process because it always feels limited with the transfer funds provided by the central government.

\section{Effect of Independence Ratio on Local Government Performance Scores}

The results of the multiple linear coefficient test showed that the level of significance of the regional financial independence ratio was $0.708>0.05$. This shows that the ratio of regional financial independence has a positive and significant effect on the performance score of local governments. From these results it can be concluded that the third hypothesis stating that the ratio of regional financial independence has a positive effect on the Government's performance score can be accepted (H3 accepted). An increase in the value of the region's financial independence ratio can partially affect the probability of an increase in the score of the local Government's performance. This indicates that the role of PAD in improving local Government performance scores has functioned as it should if seen partially.

The results of this study support research which states that regional wealth level variables affect the performance of local governments, such as research results Mustikarini dan Fitriasari (2012) which states there is a positive influence between the regional wealth level variable (PAD) on the performance score of the regional government. The study also stated that the higher the PAD owned by a local government, the higher the performance in the administration of government. In line with the above research, research Rustiyaningsih dan Immanuela (2014) also stated that partially PAD had a significant effect on the performance of local government. Almost all research on performance that examines the level of local financial independence variable on the performance of local governments, states that the regional 
financial independence variable significantly influences the performance of regional government.

Research in this variable has a significant positive effect because it can be concluded that, a regional government with a high ratio of regional financial independence means having a large PAD so that it can be more flexible in managing its government. The more freely the regional government manages its government, the higher the performance of the regional government will be. The higher the ratio of regional financial independence of the regional government, the better the performance of the regional government. When related to the existing literature, it is stated that the performance of local governments can be measured through the calculation of financial ratios which are a measure of regional financial capacity (Wahab, Rofingatun, dan Kreuta, 2016). This means that any movement in financial ratios in this case the ratio of regional financial independence can affect the probability of increasing the performance score of the local government. The higher the ratio of local financial independence of a local government, the higher the performance score obtained by the local government. 


\subsection{Conclusion}

\section{CONCLUSIONS AND SUGGESTIONS}

Based on the results of data analysis regarding the influence of audit opinion, the ratio of regional financial dependency and the ratio of regional financial independence to performance scores, the conclusions that can be drawn from this study are as follows:

1. The audit opinion and the financial capability of the South Sumatra region calculated by the proxy of dependency ratio and the regional financial capability calculated by the proxy of the independence ratio together have a significant effect on the Government of Daera's performance score in the South Sumatra region.

2. Partially the audit opinion and financial capability of the South Sumatra region calculated by the proxy of the independence ratio has a significant positive effect on the performance score of the South Sumatra regional government.

3. Partially the financial capability of the South Sumatra region calculated by the dependency ratio does not significantly influence the South Sumatra Regional Government's performance score.

\subsection{Research Limitations}

The limitations in this study include:

1. This research sample uses local governments in South Sumatra with a period of only two years, namely 2015 and 2016 so that it has not been able to generalize the research results. This study also cannot use the latest data because local government performance score data for 2017 and 2018 have not been published as Minister of Home Affairs.

2. This study initially also used audit findings variables from the BPK, but due to data limitations these variables must be eliminated so that the results of the study only produce an R square coefficient of $14.9 \%$. This result can be interpreted that of all the independent variables used in this study only affect local government performance scores of $14.9 \%$, and there are still $85.1 \%$ other variables outside this study that can affect local government performance scores.

\subsection{Research Suggestions}

By considering some of the limitations that have been submitted, it can be given some suggestions for further research, namely as follows:

1. The next researcher is expected to add a research sample, that is by expanding the research population to all local governments in Indonesia so that the sample of the local government studied is more then the research results are better and can be generalized.

2. Future studies are also expected to be able to use the latest research data, and use research data for at least 3 years in a row so as to produce more significant research results.

3. Researchers are further advised to add independent variables to audit findings such as internal control system findings, compliance with laws and follow-up to BPK findings and other independent variables that have the potential to have a greater influence on local government performance scores. 


\section{References}

[1] Arifianti, H., Payamta, \& Sutaryo. (2013). Pengaruh Pemeriksaan dan Pengawasan Keuangan Daerah terhadap Kinerja Penyelenggaraan Pemerintahan Daerah ( Studi Empiris pada Pemerintah Kabupaten / Kota di Indonesia ). Jurnal Dan Prosding SNA Simposium Nasional Akuntansi, 16, 2477-2505.

[2] Harumiati, Y., \& Payamta. (2014). Pengaruh Karakteristik Pemerintah Daerah dan Temuan Audit BPK Terhadap Kinerja Pemerintah Daerah Kabupaten/Kota di Indonesia Tahun Anggaran 2011. Jurnal Akuntansi Dan Pendidikan, 3(2), 75-87.

[3] Ikhtisar Hasil Pemeriksaan Semester II Tahun 2017. (2017). Badan Pemeriksa Keuangan Republik Indonesia.

[4] Jensen, M. C., \& Meckling, W. H. (1976). Theory of the Firm: Managerial Behavior, Agency Costs and Ownership Structure. Journal of Financial Economics, 3(4), 305-360.

[5] Keputusan Menteri Dalam Negeri Nomor 100-53 Tahun 2018. Tentang Peringkat dan Status Kinerja Penyelenggaraan Pemerintah Daerah Secara Nasional Tahun 2016.

[6] Keputusan Menteri Dalam Negeri Nomor 120-10421 Tahun 2016. Tentang Peringkat dan Status Kinerja Penyelenggaraan Pemerintah Daerah Secara Nasional Tahun 2015.

[7] Mustikarini, W. A., \& Fitriasari, D. (2012). Pengaruh Karakteristik Pemerintah Daerah dan Temuan Audit BPK Terhadap Kinerja Pemerintah Daerah Kabupaten/Kota di Indonesia Tahun Anggaran 2011. Jurnal Dan Prosding SNA - Simposium Nasional Akuntansi, 15.

[8] Nilamsari, N. (2014). Memahami Studi Dokumen dalam Penelitian Kualitatif. Wacana, XIII(2), 177-181.

[9] Nurdin, F. (2016). Pengaruh Karakteristik Pemerintah Daerah dan Temuan Audit BPK RI Terhadap Akuntabilitas Kinerja Pemerintah Daerah. Jurnal Akuntansi Dan Pendidikan.

[10] Nurhayati. (2015). Analisis Rasio Keuangan Untuk Mengukur Kinerja Pemerintah Daerah Kabupaten Rokan Hulu. Jurnal Ilmiah Cano Ekonomos, 4(1), 55-66.

[11] Peraturan Menteri Dalam Negeri Nomor 73 Tahun 2009. Tentang Tatacara Pelaksanaan Evaluasi Kinerja Penyelenggaraan Pemerintah Daerah (2009).

[12] Peraturan Pemerintah Nomor 6 Tahun 2008. Tentang Pedoman Evaluasi Penyelenggaraan Pemerintah Daerah.

[13] Peraturan Pemerintah Nomor 71 Tahun 2010. Tentang Standar Akuntasi Pemerintah (2010).

[14] Peraturan Pemerintah Nomor 8 Tahun 2006. Tentang Pelaporan Keuangan dan Kinerja Instansi Pemerintah.

[15] Radjab, E., \& Jam'an, A. (2017). Metodologi Penelitian Bisnis. Makasar: Lembaga Perpustakaan dan Penerbitan Universitas Muhammadiyah Makassar.

[16] Realisasi APBD Tahun 2015. (2015). DJPK Kementerian Keuangan Republik Indonesia. Retrieved from www.djpk.kemenkeu.go.id

[17] Realisasi APBD Tahun 2016. (2016). DJPK Kementerian Keuangan Republik Indonesia. Retrieved from www.djpk.kemenkeu.go.id

[18] Renas, D. M. (2014). Pengaruh Karakteristik Pemerintah Daerah dan Temuan Audit BPK Terhadap Kinerja Pemerintah Daerah Studi pada Pemerintah Daerah Kabupaten / Kota di Provinsi Jawa Tengah Periode 2009-2011. Diponegoro Journal of Accounting, 4(3), 1-15.

[19] Rustiyaningsih, S., \& Immanuela, I. (2014). Faktor-Faktor yang Mempengaruhi Kinerja Pemerintah Daerah. Widya Warta No. 02 Tahun XXXV III, (2), 190-202. 
[20] Saktiawati, D. H. (2014). Determinan Kinerja Penyelengaraan Pemerintah Daerah ( Studi Empiris pada Pemerintah Kabupaten / Kota di Indonesia ). GEMA, Th. XXVI/48/Februari 2014 - Juli 2014, 1381-1393.

[21] Sudarsana, H. S., \& Rahardjo, N. S. (2013). Pengaruh Karakteristik Pemerintah Daaerah dan Temuan Audit BPK Terhadap Kinerja Pemerintah Daerah (Studi pada Pemerintah Kabupaten/Kota di Indonesia). Diponegoro Journal of Accounting, 2(4), $1-13$.

[22] Undang-Undang Nomor 23 Tahun 2014. Tentang Pemerintah Daerah.

[23] Undang-Undang Nomor 32 Tahun 2004. Tentang Pemerintahan Daerah (2004).

[24] Wahab, L. O. A., Rofingatun, S., \& Kreuta, B. (2016). Analisis Kemampuan Keuangan Daerah Pemerintah Kabupaten Jayapura. Jurnal Kajian Ekonomi Dan Keuangan Daerah, 2(3), 1-12.

[25] Zelmiyanti, R. (2016). Pendekatan Teori Keagenan pada Kinerja Keuangan Daerah dan Belanja Modal (Studi pada Provinsi di Indonesia). JRAK.Vol.7 No.1.Februari 2016, 7(1), 11-21. 